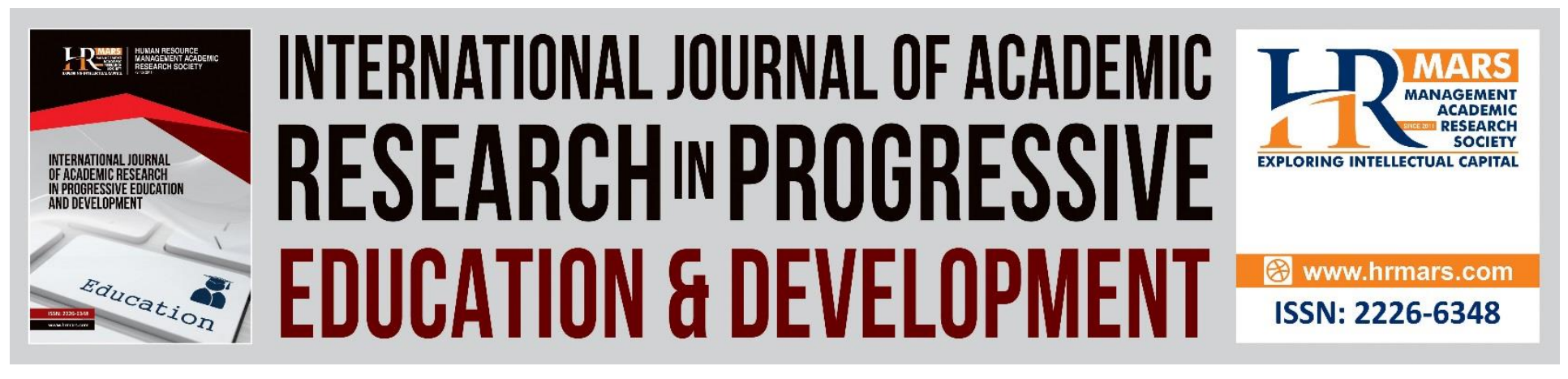

\title{
Validity and Reliability of the Teacher Leadership Inventory in Malaysian Educational Context
}

\section{Mahaliza Mansor, Jamal@Nordin Yunus, Fanny Kho Chee Yuet}

To Link this Article: http://dx.doi.org/10.6007/IJARPED/v7-i3/4566 DOI: 10.6007/IJARPED/v7-i3/4566

Received: 11 June 2018, Revised: 29 June 2018, Accepted: 13 July 2018

Published Online: 20 July 2018

In-Text Citation: (Mansor, Yunus, \& Yuet, 2018)

To Cite this Article: Mansor, M., Yunus, J., \& Yuet, F. K. C. (2018). Validity and Reliability of the Teacher Leadership Inventory in Malaysian Educational Context. International Journal of Academic Research in Progressive Education and Development, 7(3), 480-488.

\section{Copyright: (C) 2018 The Author(s)}

Published by Human Resource Management Academic Research Society (www.hrmars.com)

This article is published under the Creative Commons Attribution (CC BY 4.0) license. Anyone may reproduce, distribute, translate and create derivative works of this article (for both commercial and non-commercial purposes), subject to full attribution to the original publication and authors. The full terms of this license may be seen at: $\underline{\text { http://creativecommons.org/licences/by/4.0/legalcode }}$

Vol. 7, No. 3, July 2018, Pg. 480 - 488

http://hrmars.com/index.php/pages/detail/IJARPED

Full Terms \& Conditions of access and use can be found at http://hrmars.com/index.php/pages/detail/publication-ethics 


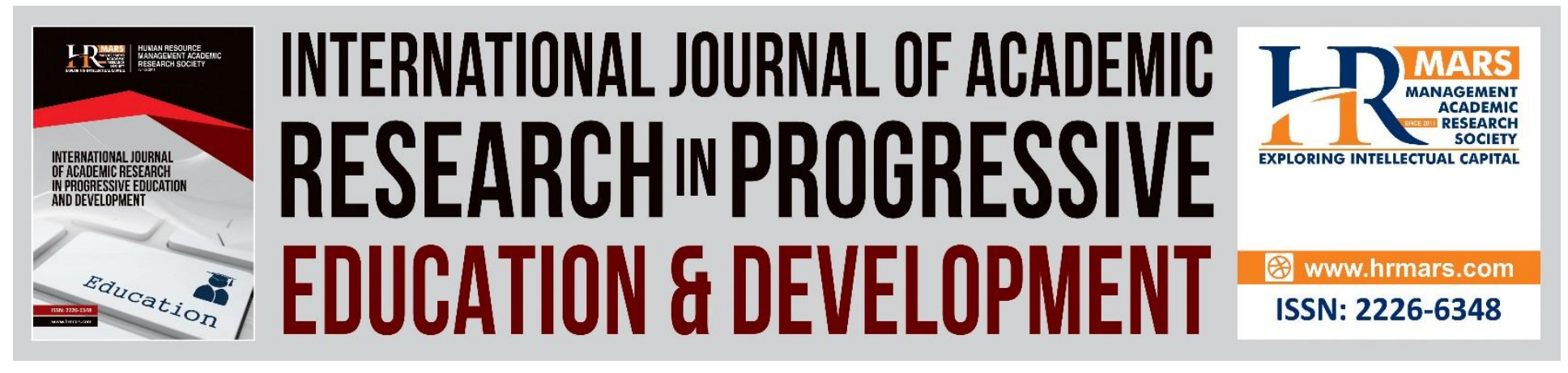

\title{
Validity and Reliability of the Teacher Leadership Inventory in Malaysian Educational Context
}

\author{
Mahaliza Mansor ${ }^{*}$, Jamal @ Nordin Yunus², Fanny Kho Chee \\ Yuet $^{3}$ \\ 1,2,3 Faculty of Management and Economic, \\ Universiti Pendidikan Sultan Idris, Tanjung Malim, Malaysia
}

\begin{abstract}
The aims of this article is to report the validity and reliability of the Teacher Leadership Self Assessment (TLSA). The sample of the study consists of 244 trained teachers who are chosen using random sampling technique from 19 secondary schools in Perak. The content validity, criterion validity and construct validity analyses have been carried out by using this set of data. The findings of this study using panel of expert views, Pearson correlation analysis and exploratory factor analysis through orthogonal rotation with varimax method has formed six factors, consisted of twenty eight-items of TLSA with factor loadings range from .52 -.74. The reliability Cronbach Alpha coefficient for the overall item is .91, meanwhile for each factor developed ranged from .66 to .83 . As the conclusion, these analyses have generate a new pool of TLSA item to measure the construct of teacher leadership in Malaysian Educational context. However, the findings are valuable for the ministry of education, researchers, teachers, and teacher educators' references, which are interested more in exploring teacher leadership self assessment.
\end{abstract}

Keywords: Teacher Leadership, Factor Analysis, Validity and Reliability

\section{Introduction}

The concept of teacher leadership began to be discussed seriously in 1992, however the scholars have different definitions for this leadership concept. Katzenmeyer and Moller (2001) as well as Killion and Harrison (2006) argued that there are many definitions of teacher leadership. Teacher leadership is a different aspect from the role of a principal as a leader in a school. According to Teacher Leadership Exploratory Consortium (2011), teachers can play their roles either formal or informal. Even though, teachers do not have any formal position in schools, they are respect by colleagues, learn continuously, easy to approach by their colleagues and always use skills and influences as team members to improve the level of educational practices with other teachers. 

DEVELOPMENT

Vol. 7, No. 3, July 2018, E-ISSN: 2226-6348 @ 2018 HRMARS

Harris (2011) has listed four characteristics of teacher leadership that should have as a teacher, namely 1 ) capable of translating the theory of school improvement into practices within the organization through collaborating with colleagues, (2) empowerment and authority to their colleagues in the organization to enable them to work together and make changes, (3) play a role as catalyst to acquire the latest expertise and information from within and out of school, and (4) become a liaison between colleagues so that the learning process can be carried out quickly, efficiently and effectively. Therefore, teacher leadership refers to the attitude of teachers who constantly strive to improve their knowledge and skills continuously, often reflecting and collaborating with the school community to make improvements both inside and out of the classroom.

The model of Leadership Development for Teachers (LDT) by Marilyn Katzenmeyer and Gyle Moller 2004, has been used in this study. The LDT model is integrated with the Teacher Leadership Self-Assessment (TLSA) instrument that has been designed by Katzenmeyer and Moller (2009). All these aspects are measured using the Teacher Leadership Self Assessment (TLSA) instrument with 42 items proposed, by Katzenmeyer and Moller (2009). The components are 1) Self-awareness and Leading Change, (3) Communication, (4) Diversity, (5) Instructional Proficiency, (6) Continuous Improvement and (7) Self-organization. Therefore, in this study researchers want to evaluate how Malaysian teachers practiced these dimensions in their working environments'. This is because leadership of the teacher can bring positive changes in the improvement of the organization in the school (Leithwood, Mulford, \& Silins, 2004).

\section{Self-Awareness and Leading Change}

Self-assessment is an aspect where teachers have an accurate picture of self in terms of strengths, values, philosophy and behavior (Katzenmeyer \& Moller, 2009; York-Barr \& Duke, 2004). Meanwhile, Hawkins-Revis (2007) notes that 78 percent of teachers see their position as capable teachers, hence they provide suggestions to unsolicited teachers. Therefore, self assessment is the attitude of the teacher who performs self-reflection from time to time and improves themselves to bring positive changes in the quality of themselves and the school organization (Fairman \& Mackenzie, 2012). However, leading change refers to teachers demonstrate commitment to uses effective strategies to facilitate positive change (Katzenmeyer \& Moller, 2009). Teacher leadership has an impact on school reform initiatives (York-Barr \& Duke, 2004; Robinson, 2009; Fairman \& Mackenzie, 2012). Therefore, continuous improvement is the practice of teachers with their colleagues in planning, acting and evaluating to reform the school systems that leads to school improvement.

\section{Communication}

Teachers exhibits effective listening skills, oral communication, presentation skills and expressions in written communication (Katzenmeyer \& Moller, 2009; Fairman \& Mackenzie, 2012). Communication skills are the medium for establishing good relationships in human life (Ahmad, Mahamod, \& Aziz, 2012 ; York-Barr \& Duke, 2004). Hence, the teachers should have good communication skills such as listen effectively, convey meaningful language and good writing skills to create a good rapport with school community. 
INTERNATIONAL JOURNAL OF ACADEMIC RESEARCH IN PROGRESSIVE EDUCATION AND DEVELOPMENT

Vol. 7, No. 3, July 2018, E-ISSN: 2226-6348 @ 2018 HRMARS

\section{Diversity}

Teacher demonstrates respect for and responds to differences in perspectives (Katzenmeyer \& Moller, 2009). Van Maele and Van Houtte (2011), stated that teachers needed to improve the quality of teachers' social relationships at work, because they found that it will improve the quality and job satisfaction of the teachers. Therefore, diversity is the ability of teachers in maintaining good social relationships among the school community, as the teachers who always respect the different perspectives of other teachers (York-Barr \& Duke, 2004; Fairman \& Mackenzie, 2012).

\section{Instructional Proficiency And Leadership}

Teachers possess and employ professional knowledge and skills in providing the most effective learning opportunities for students and adults (Katzenmeyer \& Moller, 2009; York-Barr \& Duke, 2004). Pedagogical skills and knowledge used by teachers are critical factors in creating and maintaining school improvements (Hallam, Chou, Hite, \& Hite, 2012). Thus, teaching skills is the ability of teachers to use their own knowledge and skills to guide students and colleagues to enhance organizational achievement (Fairman \& Mackenzie, 2012).

\section{Self-organization}

Teachers establish course of action and implements plans to accomplish the best results (Katzenmeyer \& Moller, 2009; Fairman \& Mackenzie, 2012). Nowadays, teachers become agents of change those are very important to ensure that the school becomes an effective school where every student has the same opportunity to get teachers who have high self-esteem (Wehling, 2007; York-Barr \& Duke, 2004). Therefore, self-organization is the attitude of competence and motivation of teachers in organizing themselves by gaining the balance between profession and personal affairs in implementing the task entrusted to them in school.

Currently, there are still not many suitable instruments to measure secondary school teachers ' perception toward teacher leadership. Most of the previous studies have been carried in Western countries by using Teacher Leadership Self Assessment (TLSA) developed by Katzenmeyer and Moller (2009) and the measurement is not really suitable with Malaysian context as well as less has been reviewed by previous researcher. Secondly, is the use of suitable statistical procedure in developing and validating items. The exploratory factor analysis has been well suggested by experts if there are less research have been carried out regarding the observe factor structure (Bandalos \& Finney, 2010; Hayton, Allen \& Scarpello, 2004). Given these various constraints and limitations of existing instrument reviewed, it was therefore necessary to develop an empirically validated Teacher Leadership Self Assessment (TLSA) specifically in measuring perceptions, for Malaysian secondary school teachers. The use of EFA, criterion validity and, content validity as well as internal consistency are more suitable in developing and validating items.

Therefore, the purpose of this paper is to discuss the development, validity and reliability of Teacher Leadership Self Assessment (TLSA). The purpose has been divided into: (a) generate an initial pool of items for a scale to measure the construct of Teacher Leadership Self Assessment 
INTERNATIONAL JOURNAL OF ACADEMIC RESEARCH IN PROGRESSIVE EDUCATION AND DEVELOPMENT

Vol. 7, No. 3, July 2018, E-ISSN: 2226-6348 @ 2018 HRMARS

(TLSA) among teachers; (b) to conduct an EFA to assess the factor structure of the scale items; (c) to investigate the estimate of construct validity and internal consistency of Teacher Leadership Self Assessment (TLSA).

\section{Questionnaire Design}

The questionnaire is composed of seven parts, 42 items including: Self-Awareness and Leading Change, Communication, Diversity, Instructional Proficiency and Leadership, Continuous Improvement, and Self-organization. The questionnaire items were answered using a five-point scale anchoring at 1, 2, 3, 4 and 5 (never, rare, sometimes, often and always). According to Babbie (2007), this scale is suitable to measures teachers' attitudes as well as opinions. Furthermore, this five-point scale (without central tendency) is suitable to use in East Asian respondents, where the 'doctrine of mean' is advocated in the culture (Cohen, Manion\& Morrison, 2007). The instrument used has been adopted from Katzenmeyer \& Moller (2009).

\section{Factor Analysis, Validity and Reliability}

This section will discuss about sampling procedure, factor analysis, validity and reliability.

\section{Sampling}

The data used in this research was obtained from 19 regular secondary schools in Batang Padang district in Perak. This set of data was used in preliminary study as to perform exploratory factor analysis. Fifteen sets of questionnaires were distributed to each of these 19 regular secondary schools. Two hundred eighty five survey forms were circulated, of which 244 surveys were return and valid for analysis.

\section{Validity and Reliability Analyses}

The Cronbach Alpha coefficients were used to measures the internal consistency of these scales (Nunnally \& Bernstein, 1994). In this study, the constructs that had Cronbach Alpha coefficients greater than .70 have been retained for further analysis (Hair, Black, Babin, Anderson \&Tatham, 2010; Hancock, Mueller, \& Stapleton, 2010). Furthermore, measures with item-to-total correlation larger than 0.3 are considered to have criterion validity (Hair et al, 2010). The itemto-total correlation of each measure was more than .3; we consider the criterion validity of each scale to be satisfactory.

The original questionnaire was translated into Malay language twice by language experts using the 'back technique`. The items are reviewed by a panel of Sultan Idris Education University lecturers to ensure the translation of meaning and terminology met the theoretical background as the technique was recommended by Sireci, Yang, Harter and Ehrlich (2006). The panel consists of an assessment and measurement expert, and two educational leadership experts.

Then, the questionnaires have been administered to six trained teachers to identify if there were any confusion regarding the items and record it in the space provided for improvements or been dropped out (Johnson \& Christensen, 2008; Choi, Fuqua, \& Newman, 2009). The purpose was to improve the items and to ensure it was suitable for Malaysian context. Furthermore, it was important to get feedback on quality of each item, as it was easy to understand and used the 


\section{INTERNATIONAL JOURNAL OF ACADEMIC RESEARCH IN PROGRESSIVE EDUCATION AND}

DEVELOPMENT

Vol. 7, No. 3, July 2018, E-ISSN: 2226-6348 @ 2018 HRMARS

appropriate language and terminology. The samples were asked to evaluate about the clarity of each items by using the scale given (Choi, Fuqua, \& Newman, 2009). A scale of 1 to 10 is used to determine the validity coefficient for each item. According to Tuckman and Waheed (1981) in Mohd Noah and Ahmad (2005) if the total of the score obtained from the experts is $70 \%$ or above, it means that the item has a high score for the content validity aspect. Otherwise, the item will be dropped from the questionnaires. The results of content validity are presented in Table 1 below.

Table 1: Content validity scores

\begin{tabular}{lccccccc}
\hline Panel & Panel 1 & Panel 2 & Panel 3 & Panel 4 & Panel 5 & Panel 6 & $\begin{array}{l}\text { Cumulative } \\
\text { Score }\end{array}$ \\
\hline $\begin{array}{l}\text { Percentage } \\
(\%)\end{array}$ & 92.72 & 91.51 & 88.48 & 82.42 & 82.42 & 80.00 & 86.84 \\
\hline
\end{tabular}

Meanwhile, to ensure the instrument has reasonable construct validity, exploratory factor analysis was used. The exploratory factor analysis (EFA) through orthogonal rotation with varimax method had been used on these 42 items. The EFA applied the following rules as suggested by Hair et al. (2010) and Tabachnick and Fidell (2007):

i. $\quad$ Bartlett's Test of Sphericity had to be significant $(p<.05)$;

ii. Kaiser-Meyer-Olkin measure of sampling index $\geq .5$;

iii. $\quad$ Eigenvalue $>1$;

iv. Items with the factor loading $>.5$ were retained;

v. Three items per factor

vi. Factors building were based on teacher leadership models and previous studies.

The results of exploratory factor analysis are presented in Table 2.

Table 2: Exploratory factor analysis and internal consistency values for the questionnaires

\begin{tabular}{|c|c|c|c|c|c|c|c|}
\hline Construct & Factor & $\begin{array}{c}\text { Number } \\
\text { of item } \\
\text { per } \\
\text { construct }\end{array}$ & Communalities & $\begin{array}{l}\text { Factor } \\
\text { loading }\end{array}$ & $\begin{array}{c}\% \text { of } \\
\text { variance }\end{array}$ & $\begin{array}{l}\text { Cumulative } \\
\text { percentage }\end{array}$ & $\begin{array}{c}\text { Cronbach's } \\
\alpha\end{array}$ \\
\hline $\begin{array}{l}\text { Teacher } \\
\text { Leadership }\end{array}$ & 6 & 28 & $.40-.70$ & $\begin{array}{l}.52- \\
.74\end{array}$ & & 52.61 & .91 \\
\hline Self-Awareness & & 4 & $.42-.63$ & $\begin{array}{l}.58- \\
.72\end{array}$ & 10.32 & & .83 \\
\hline Communication & & 3 & $.40-.59$ & $\begin{array}{l}.58- \\
.74\end{array}$ & 6.77 & & .66 \\
\hline Diversity & & 5 & $.51-.64$ & $\begin{array}{l}.62- \\
.67\end{array}$ & 8.35 & & .70 \\
\hline $\begin{array}{l}\text { Instructional } \\
\text { Proficiency And } \\
\text { Leadership }\end{array}$ & & 6 & $.59-.64$ & $\begin{array}{l}.57- \\
.71\end{array}$ & 11.1 & & .73 \\
\hline $\begin{array}{l}\text { Continuous } \\
\text { Improvement }\end{array}$ & & 6 & $.48-.64$ & $\begin{array}{c}.52- \\
68\end{array}$ & 10.99 & & .73 \\
\hline $\begin{array}{l}\text { Self- } \\
\text { organization }\end{array}$ & & 4 & $.51-.70$ & $\begin{array}{l}.55- \\
.74\end{array}$ & 5.02 & & .77 \\
\hline
\end{tabular}




\section{Discussion and Conclusion}

The purpose of this study is to develop and validate teacher leadership inventory used to measure secondary teachers ' perception in Malaysian setting. This study is based on Teacher Leadership Self Assessment (TLSA) developed by Katzenmeyer and Moller (2009) and used statistical approach to identify twenty eight-items in developing new Teacher Leadership Self Assessment. The Egien values showed that there are six factors, which score more than one, and the total cumulative percentage is $52.61 \%$. The communalities values ranged from .40 to .70 , mean while the factor loadings for each constructs ranged from .52 to 74 which in a good range. However, only twenty eight-items have been accepted and pooled to form TLSA final version. Fourteen items have been removed according to the factor loading less then .5. One factor has been excluded after the analysis, namely Leading Change. The factors remain are Self-Awareness, Communication, Diversity, Instructional Proficiency and Leadership, Continuous Improvement and Self-organization as suggested by pervious literatures as shown in Table 2. Results from this study suggested that TLSA and its constructs shown the good internal consistency values to assess teacher leadership. The overall internal consistency value is .91, meanwhile the values of each constructs range from .66 to .83 for this study. Therefore, these items are suitable to use in exploratory research (Nunnally \& Bernstein, 1994).

This study has a few weakness, such as the comparison of the values of internal consistency among the studies cannot be done extensively and rigorously because less of reviewed inventory. Secondly, the sample only consisted of secondary school; therefore, the next study should be extended to primary school teachers. Thirdly, the use of confirmatory factor analysis (CFA) is more suitable in developing and validating items. As the CFA can be used as a basis for a final determination regarding an underlying construct, because this analysis is designed to maximize the amount of variance within the current variable set, and subsequent analyses with other data sets may not reproduce the same factor structure. Furthermore, EFA only focus on statistical and not according to the theory in determining the measurement structure scale as well as not enough to measure error (Henson, Capraro \&Capraro, 2004). Further study also should be explored on the perception of the teachers on the existence of other teacher leadership models. However, the findings are valuable for the researchers, teachers, and teacher educators' references, which are interested more in exploring teacher leadership.

\section{Acknowledgement}

This research is funded by University Research Grant (2017- 0166 -106-01).

Corresponding Author: Mahaliza Mansor

Email: mahaliza@fpe.upsi.edu.my

\section{References}

Ahmad, N., A, Mahamod, Z., \& Aziz, Z. (2012). Pengajaran komunikasi bagi murid-murid bermasalah pembelajaran teruk. Jurnal Pendidikan Bahasa Melayu, 2 (2): 11-18

Babbie, E. (2007). Practice of social research. United States: Cengage Learning.

Bandalos, D. L. \& Finney, S. J. (2010) Factor analysis: Exploratory and confirmatory . Dalam G. R. 
INTERNATIONAL JOURNAL OF ACADEMIC RESEARCH IN PROGRESSIVE EDUCATION AND

DEVELOPMENT

Vol. 7, No. 3, July 2018, E-ISSN: 2226-6348 @ 2018 HRMARS

Hancock dan R. O. Mueller (Eds.), The reviewer's guide to quantitative methods in the social sciences (pg. 94-114). New York: Routledge.

Breakwell, P. G., Hammond, D. S. M., Fife-Schaw, D. C., \& Smith, P. J. A. (2006). Research methods in psychology. Thousand Oaks: Sage Publications.

Child, D. (2006). The essentials of factor analysis. London: Continuum International Publishing Group.

Choi, N., Fuqua, D. R., \& Newman, J. L. (2009) Exploratory and confirmatory studiesof the structure of the bem sex role inventory short form with two divergentsamples. Educational and Psycological Measurement, 9 (4), 696-705.

Cohen, L., Manion, L., \& Morrison, K. (2007). Research methods in education. New York: Routledge.

Fairman, J. C., \& Mackenzie, S. V. (2012). Spheres of teacher leadership action for learning. Professional Development in Education. 38(2), 267-286.

Field, A. (2009). Discovering statistic using SPSS. Singapore: SAGE Publication.

Hair, J. F., Black, W. C., Babin, B. J., Anderson, R. E., \&Tatham R., L. (2010).Multivariate data analysis. New Jersey: Pearson Prentice Hall.

Hallam, P., Chou, P., Hite, J., \& Hite, S. (2012). Two contrasting models for mentoring as they affect retention of beginning teachers. NASSP Bulletin, 96(3), 243-278.

Hancock, G. R., Mueller, R. O., \& Stapleton, L. M. (Eds.). (2010). The reviewer's guide to quantitative methods in the social sciences. Routledge.

Harris, A. (2011). System improvement through collective capacity building. Journal of Educational Administration. 49.6, 624-636.

Henson, R., K., Capraro, R., M.,\& Capraro, M., M. (2004). Reporting practice and use of exploratory factor analysis in educational research journals. Research in the school, 11, 61-72.

Hawkins-Revis, J. (2007). Advancing teacher leadership capacity: Teacher's Leaders' Perceptions of Social and Organizational Structures on teacher-leader and Teacher Interactions. (Doctoral Dissertation).

Hayton, J., C., Allen, D., G., \&Scarpello, V. (2004). Factor retention decisions in exploratory factor analysis: A tutorial on parallel analysis. Organizational Research Methods, (7),191 DOI: $10.1177 / 1094428104263675$.

Henson, R. K. \& Roberts, J. K. (2006). Use of exploratory factor analysis in publishedresearch common errors and some comment on improved practice. Educational and Psycological Measurement, 66(3), 393-416.

Johnson, R., B., \& Christensen, L. B. (2008). Educational research: Quantitative, qualitative, and mixed approaches. Thousand Oaks: Sage Publications.

Katzenmeyer, M, \& Moller, G. (2001). Awakeing the Slepping Giant: Leadership Development for Teachers ( $2^{\text {nd }}$ Edition). Thousand Oaks, California: Corwin Press Inc.

Katzenmeyer, M, \& Moller, G. (2009). Awakeing the Slepping Giant: Leadership Development for Teachers ( $3^{\text {rd }}$ Edition). Thousand Oaks, California: Corwin Press Inc.

Killion, J., \& Harrison C. (2006). Taking the lead: New lead roles for teachers and school-based coaches. Oxford, $\mathrm{OH}$ : National Staff Development Council.

Leithwood, K., Mulford, W., \& Silins, H. (2004). Educational Leadership for Organisational Learning and Improved Students Outcomes. New York: Kluwer Academic Publisher. 
INTERNATIONAL JOURNAL OF ACADEMIC RESEARCH IN PROGRESSIVE EDUCATION AND DEVELOPMENT

Vol. 7, No. 3, July 2018, E-ISSN: 2226-6348 @ 2018 HRMARS

Mohd Noah, S., \& Ahmad, J. (2005). Pembinaanmodul: Bagaimana membina modul latihan dan modul akademik.Serdang: Penerbit UPM.

Nunnally, J.C. \& Bernstein, I. H. (1994). Psychometric theory. New York: McGraw-Hill.

Robinson, J. (2009). Teachers leadership and school reform: A case study of the Accelerating student achievement Project in a central Kentucky school district. (Doctoral dissertation).

Sireci, S. G., Yang, Y., Harter, J., \& Ehrlich, E. J. (2006). Evaluating guidelines for test adaptations: A methodological analysis of translation quality. Journal of Cross-Cultural Psychology, 37(5), 557-567. doi:10.1177/0022022106290478

Tabachnick, B., G., \&Fidell, L. (2007). Using multivariate statistic. Boston: Allyn andBacon.

Teacher Leadership Exploratory Consortium. (2011). Teacher Leader Model Standard. http://www.teacherleaderstandards.org/teacher-leadership-exploratory-consortium

Van Maele, D., \& Van-Houtte. (2011). The role of teacher and faculty trust in forming teachers'job satisfaction: Do years of experience make a difference? Teaching and Teacher Education, 28(6), 879-889.

Wehling, B. (2007). Building a $21^{\text {st }}$ Century U.S Education System. Washington, DC: The National Commission on Teaching and America's Future (NCTAF).

York-Barr, J., \& Duke, K. (2004). What do we know about teacher leadership? Findings from two decades of scholarship. Educational Research, 74, 255-316. 